\title{
Severe osteoporosis with multiple spontaneous vertebral fractures in a young male carrying triple polymorphisms in the vitamin D receptor, collagen type 1 , and low-density lipoprotein receptor-related peptide 5 genes
}

\author{
Maria P. Yavropoulou, ${ }^{1}$ Panagoulia Kollia, ${ }^{2}$ Dimitris Chatzidimitriou, ${ }^{3}$ \\ Stavroula Samara, ${ }^{2}$ Lemonia Skoura, ${ }^{3}$ John G. Yovos ${ }^{1}$ \\ ${ }^{1}$ Division of Endocrinology and Metabolism, $1^{\text {st }}$ Department of Internal Medicine, AHEPA University hospital, Aristotle \\ University of Thessaloniki, Thessaloniki, Greece; '2Department of Genetics and Biotechnology, Faculty of Biology, School \\ of Physical Sciences, University of Athens, Athens, Greece; ${ }^{3}$ Department of Microbiology, Medical School, Aristotle \\ University of Thessaloniki, Thessaloniki, Greece
}

\begin{abstract}
Osteoporosis is a common disease with a strong genetic component. Several studies have reported the vitamin D receptor (VDR), collagen type I (COL1A1), and LDL receptor-related protein 5 (LRP5) genes as the most likely candidates. However, most of the studies have been carried out in postmenopausal women and older men and show inconsistent results. CASE PRESENTATION: We report a case of a 26-year old male who presented with severe back pain of acute onset, unrelated to any kind of trauma, and diffuse myalgia. Imaging of the lumbar and the thoracic spine revealed two Grade 3, according to Genant's semiquantitative method, vertebral fractures in T10 and T11 and multiple Grade 1 and 2 fractures from T8 to L2. Measurement of bone mineral density (BMD) by dual-energy X-ray absorptiometry (DXA) (Lunar Prodigy) showed severe osteoporosis of the lumbar spine $\left(\mathrm{Z}\right.$-score $\left.=-3.0, \mathrm{BMD}=0.866 \mathrm{gr} / \mathrm{cm}^{2}\right)$. A complete laboratory and biochemical work-up was performed to exclude secondary causes of osteoporosis. Total genomic DNA was extracted from peripheral blood and was used as a template for genotype analysis. The patient was heterozygous for the p.V667M mutation of the LRP5 gene and for the BsmI [g.63980 G $\rightarrow \mathrm{A}, \mathrm{rs1544410]}$ and $\mathrm{Sp} 1$ polymorphisms [g.6252 G $\rightarrow \mathrm{T}$, rs1800012] of the VDR and COL1A1 genes, respectively. Further genotype analysis excluded types of osteogenesis imperfecta associated with mutations in the COL1A1 and COL1A2 genes. CONCLUSION: We herein show that the co-existence of three polymorphic sites in the VDR,
\end{abstract}


COL1A1, and LPR-5 genes in a young male adult caused severe osteoporosis with multiple fractures, suggesting a combined effect and/or interaction between these genes.

Key words: COL1A1 polymorphism, Idiopathic osteoporosis, LRP-5 mutation, Multiple fractures, VDR polymorphism, Young adult

\section{INTRODUCTION}

Osteoporosis is a systemic skeletal disease characterized by low bone mass and abnormal bone microarchitecture leading to increased fracture risk. ${ }^{1}$ In postmenopausal women and men aged 50 and above, estrogen deficiency, vitamin D deficiency, secondary hyperparathyroidism, and age-related changes in bone tissue contribute to accelerated bone loss and increased bone fragility. ${ }^{2-4}$

Low bone mass in children and young adults does not necessarily imply skeletal fragility unless the patient sustains low trauma or atraumatic fractures. ${ }^{5}$ Low bone mass in young adults could represent either attainment of low peak bone mass in relation to their body size, pubertal timing, and environment during growth, ${ }^{6,7}$ a pathological condition with bone fragility due to chronic diseases and secondary causes of osteoporosis, or a genetically predisposed/idiopathic condition. ${ }^{8}$ Osteoporosis is considered to be a disease with a strong genetic component of about $40-60 \%$. Polymorphisms and/or mutations in vitamin D receptor $(V D R)$, the collagen type I alpha1 (COL1A1), and the low-density lipoprotein receptor related-protein 5 (LRP5) genes have independently shown significant associations with bone mineral density and increased fracture risk. In addition, in genome-wide association studies, several single nucleotide polymorphisms (SNPs) have been identified as being associated with bone density or fracture risk at the genome-wide significance level. ${ }^{9-11}$ However, most of these studies concern postmenopausal women and men aged above 50 years, while data on younger individuals are scarce. We present a case of a young male adult with severe osteoporosis and multiple atraumatic vertebral fractures in whom, after exclusion of a chronic disease and other secondary causes of osteoporosis, a genetic background of polymorphisms and mutation in all three $V D R, C O L 1 A 1$, and LRP5 genes was revealed.

\section{CASE PRESENTATION}

A 26-year old male was referred to our center due to severe back pain of acute onset, unrelated to any kind of trauma, and diffuse myalgia. During the past 6 months, the patient had visited the outpatient clinics of the Rheumatology and the Orthopedic departments several times complaining of diffuse pain of moderate intensity along the spine, which was aggravated when lying in bed or sitting. At that time he was diagnosed with seronegative spondyloarthritis and was prescribed non-steroidal anti-inflammatory drugs and methotrexate. His clinical condition, however, was not improved. His medical record was free of any kind of systemic disease, as was also his family medical record. More specifically, there was no family history of frequent fractures, childhood or adolescent osteoporosis, osteogenesis imperfecta, gross skeletal anomalies, rickets, discoloured sclera, or early onset of hearing loss. Clinical examination revealed no other abnormalities.

X-rays and magnetic resonance imaging (MRI) of the lumbar and the thoracic spine revealed two Grade 3, according to Genant's semiquantitative method, vertebral fractures in Th10 and Th11 and multiple Grade 1 (T12, L1) and Grade 2 (T8, T9, L2) fractures (Figure 1). Measurement of bone mineral density (BMD) by dual-energy X-ray absorptiometry (DXA) (Lunar Prodigy) showed severe osteoporosis of the lumbar spine $\left(Z\right.$-score $=-3.0, \mathrm{BMD}=0.866 \mathrm{gr} / \mathrm{cm}^{2}$ ) (Figure 2). A complete laboratory and biochemical work-up was performed to exclude secondary causes of osteoporosis (Table 1). The patient was found to have low-normal levels of 25-OH-vitamin D and was prescribed cholecalciferol 2200 units/d per os.

\section{GENETIC ANALYSIS}

Total genomic DNA was extracted from peripheral blood and was used as a template for genotype analysis. 


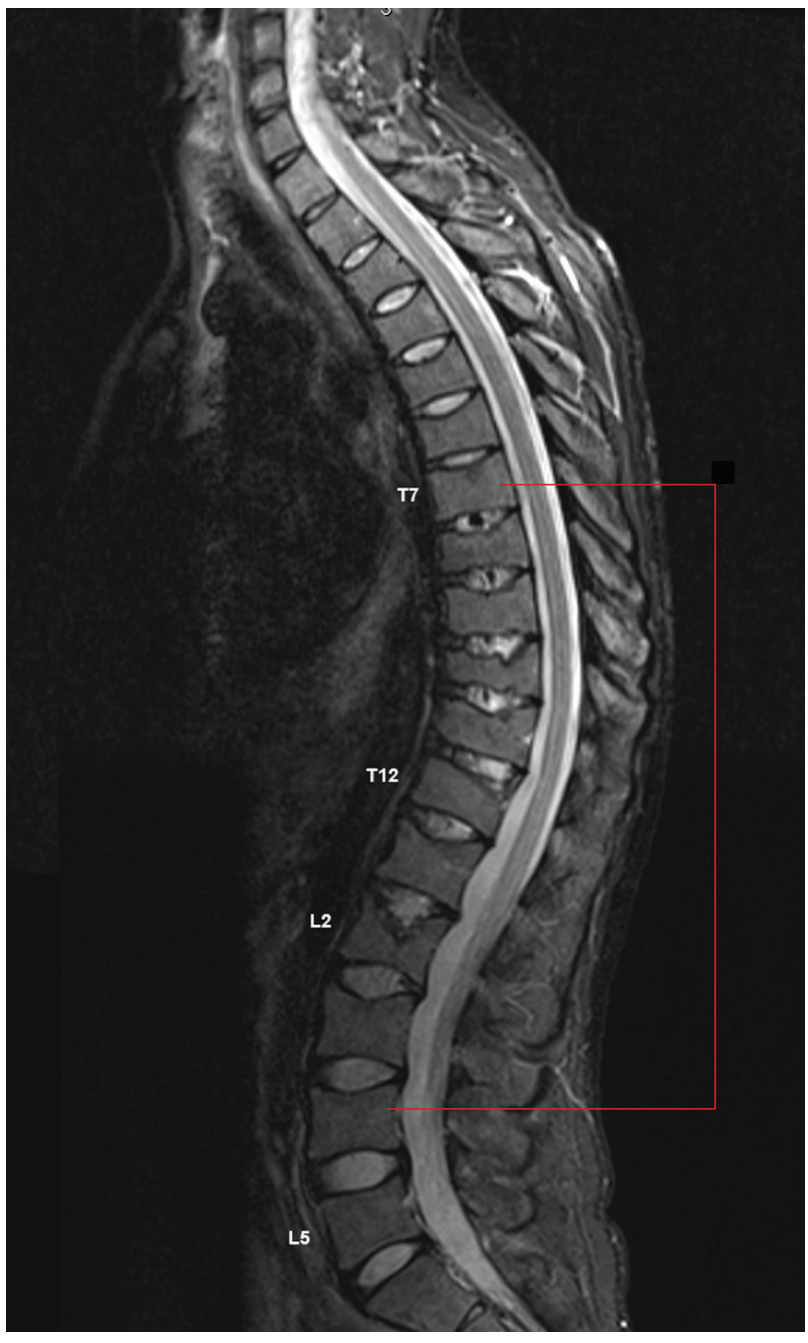

Figure 1. MRI of the thoracic and lumbar spine.

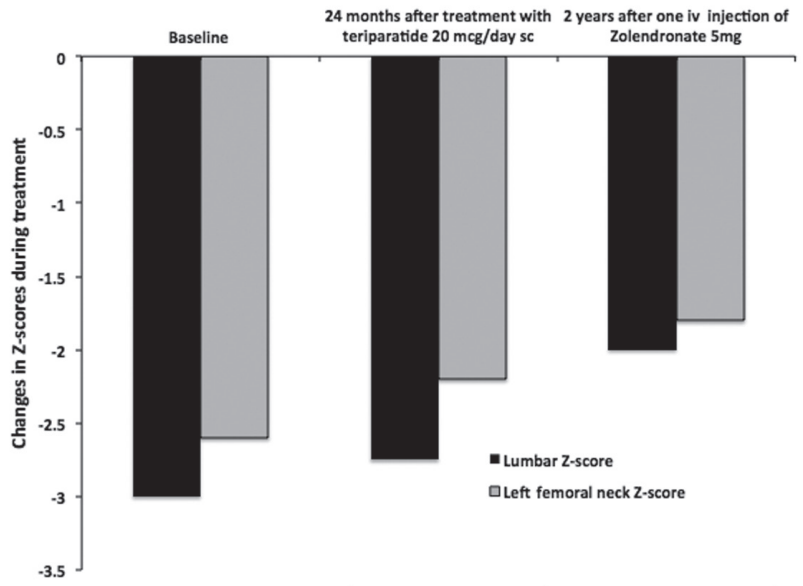

Figure 2. Changes in Z-scores of the lumbar spine and left femoral neck during treatment with teriparatide $(20 \mathrm{mcg} /$ day sc) and zolendronate (5mg single iv injection).
Table 1. Laboratory work up and baseline hormone profile at the day of admission

\begin{tabular}{|c|c|c|}
\hline Assay & Normal Range & Value \\
\hline Hematocrit (Hct) & $38.8-50.0 \%$ & $42 \%$ \\
\hline Fasting blood glucose & $3.9-5.5 \mathrm{mmol} / \mathrm{L}$ & 4.2 \\
\hline $\begin{array}{l}\text { Alanine aminotransferase } \\
\text { (ALT) }\end{array}$ & 7-56 U/L & 34 \\
\hline $\begin{array}{l}\text { Aspartate aminotransferase } \\
\text { (AST) }\end{array}$ & $10-40 \mathrm{U} / \mathrm{L}$ & 22 \\
\hline Alkaline phosphatase (ALP) & $25-100 \mathrm{U} / \mathrm{L}$ & 44 \\
\hline Serum creatinine levels & $80-110 \mu \mathrm{mol} / \mathrm{L}$ & 92 \\
\hline Ionized calcium & $1.1-1.35 \mathrm{mmol} / \mathrm{L}$ & 1.2 \\
\hline Phosphate & $0.8-1.5 \mathrm{mmol} / \mathrm{L}$ & 0.92 \\
\hline $\begin{array}{l}\text { Parathyroid hormone }(\mathrm{PTH}) \\
(\mathrm{pg} / \mathrm{ml})\end{array}$ & $10-65$ & 35 \\
\hline 25-OH-vitamin D levels & $75-250 \mathrm{nmol} / \mathrm{L}$ & 77 \\
\hline 24-Hour urine calcium & $15-20 \mathrm{mmol} / 24 \mathrm{~h}$ & 18.7 \\
\hline Magnesium & $1.5-2 \mathrm{mEq} / \mathrm{L}$ & 1.75 \\
\hline $\begin{array}{l}\text { Thyroid-stimulating hormone } \\
\text { (TSH) level }\end{array}$ & $0.5-5 \mathrm{mIU} / \mathrm{L}$ & 3.2 \\
\hline Ferritin & $33-450 \mathrm{pmol} / \mathrm{L}$ & 104 \\
\hline Serum iron & $10.7-26.9 \mathrm{pmol} / \mathrm{L}$ & 15 \\
\hline Testosterone levels & $10-25 \mathrm{nmol} / \mathrm{L}$ & 20 \\
\hline 24-Hour urine free cortisol & $9.66-124.2 \mathrm{nmol} / 24 \mathrm{~h}$ & 32 \\
\hline Morning serum Cortisol & $7-28 \mu \mathrm{g} / \mathrm{dL}$ & 16 \\
\hline \multicolumn{3}{|l|}{ Serum protein electrophoresis } \\
\hline albumin & $38-50 \mathrm{~g} / \mathrm{L}$ & 40 \\
\hline alpha-1 globulin & $1-3 \mathrm{~g} / \mathrm{L}$ & 2.2 \\
\hline alpha-2 globulin & $6-10 \mathrm{~g} / \mathrm{L}$ & 7.5 \\
\hline beta globulin & $7-14 \mathrm{~g} / \mathrm{L}$ & 8.1 \\
\hline gamma globulin & $7-16 \mathrm{~g} / \mathrm{L}$ & 8.9 \\
\hline $\begin{array}{l}\text { Antigliadin antibodies (IGA/ } \\
\text { IGG) }\end{array}$ & & $\begin{array}{c}\text { Not } \\
\text { detected }\end{array}$ \\
\hline Antiendomysial antibodies & & $\begin{array}{c}\text { Not } \\
\text { detected }\end{array}$ \\
\hline Serum tryptase & $<11.4 \mathrm{ng} / \mathrm{mL}$ & 3.2 \\
\hline Rheumatoid factor & $<25 \mathrm{IU} / \mathrm{ml}$ & 17 \\
\hline
\end{tabular}

Types of osteogenesis imperfecta associated with mutations in the COL1A1 and COL1A2 genes were excluded. 
We subsequently performed genotype analysis for genes known to correlate with the genetic background of osteoporosis, such as LRP5, VDR and COL1A1, using a novel Real-Time PCR assay based on SimpleProbe ${ }^{\circledR}$ melting curve analysis. The patient was found to be heterozygous for the p.V667M mutation of the LRP5 gene and for the BsmI [g.63980 $\mathrm{G} \rightarrow \mathrm{A}, \mathrm{rs} 1544410$ ] and $\mathrm{Sp} 1$ polymorphisms [g.6252 $\mathrm{G} \rightarrow \mathrm{T}$, rs1800012] of the VDR and COL1A1 genes, respectively.

\section{TREATMENT AND FOLLOW-UP}

The patient was treated with daily s.c injections of recombinant teriparatide for 24 months and supplementation with calcium ( $1000 \mathrm{mg} /$ daily) and vitamin D (800 IU/daily). During the first 6 months of treatment, his back pain and diffuse myalgia improved significantly and the patient did not sustain a new vertebral or non-vertebral fracture. After the completion of the 24-month teriparatide-treatment the patient showed significant gains in the bone mass of the lumbar spine $\left(\mathrm{Z}\right.$-score $=-2.2, \mathrm{BMD}=0.970 \mathrm{gr} / \mathrm{cm}^{2}$ ) and received an i.v injection of zoledronate $5 \mathrm{mg}$. Two years later the patient was free of symptoms: he had a BMD measurement in the osteopenic range in the lumbar spine and left femoral neck (Figure 2), there was no history of new fractures, and there were no new morphometric fractures in the thoracic and lumbar spine based on new X-rays. Serum levels of bone formation and bone resorption markers remained in the lower quartiles (Figure 3). In addition to antiosteoporotic treatment, the patient was subjected to a rehabilitation program because of his long-lasting immobilization due to pain and fear of falling. The program included strengthening in joint mobility, clearance in the extremities and back muscles, posture exercises, and walking training. At the end of treatment, significant improvements were observed in walking, lower and upper extremity muscle strength levels, and posture.

\section{DISCUSSION}

The BsmI polymorphic site of the $V D R$ gene, as well as the polymorphic Sp1 binding site of the COL1A1 gene, and the V667M mutation of the LRP5 gene have been independently associated with osteoporosis and fracture risk. We herein show that the co-existence

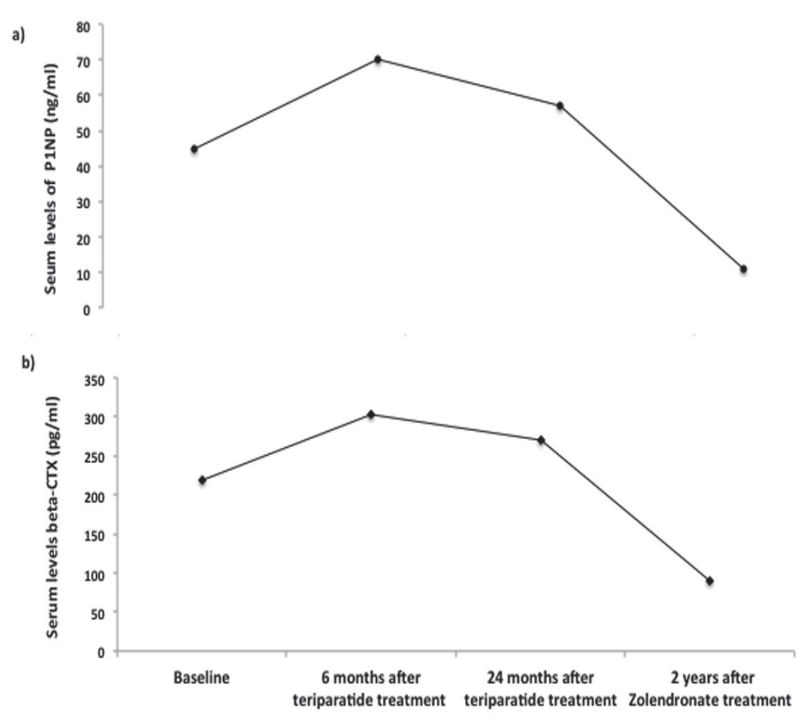

Figure 3. Changes in serum levels of the bone formation markers P1NP (a) and the bone resorption marker beta-CTX (b) during treatment with teriparatide $(20 \mathrm{mcg} / \mathrm{day} \mathrm{sc})$ and zolendronate (5mg single iv injection).

of these three genetic changes in a young male adult caused severe osteoporosis with multiple fractures, suggesting a combined effect and/or interaction between these genes.

The $V D R$ gene was among the first candidate genes studied for association with osteoporosis. ${ }^{12}$ The active metabolite of vitamin D (1,25 OH D3) acts through its specific receptor, VDR, which is a nuclear transcription factor regulating the expression of the target genes through binding to vitamin D responsive elements. ${ }^{13}$ Mutations at the key sites of the VDR gene have been reported to cause vitamin $\mathrm{D}$ deficiency even when vitamin $\mathrm{D}$ itself is supplemented adequately. ${ }^{14}$ This was a critical finding since insufficient serum levels of 25-OH-vitamin D are a well-established risk factor for osteoporosis and increased fracture risk. ${ }^{15}$ In our case, the initial symptoms of diffuse myalgia, which could be attributed to low vitamin D levels, were successfully treated with vitamin D supplementation. The most frequently studied polymorphisms of the $V D R$ gene in association with osteoporosis include BsmI, ApaI, TaqI, FokI,${ }^{16}$ and Cdx2. ${ }^{17,18}$ The effect of the VDR genotype on BMD has been found to be stronger in premenopausal women and to decrease with age, ${ }^{19}$ but several studies have produced inconsistent results with some showing positive $\mathrm{e}^{20-23}$ or no association between VDR gene polymorphisms 
and BMD values. ${ }^{24-26}$ Association of fracture risk with $V D R$ polymorphisms has also been a matter of debate, with one showing significant association of BsmI and fracture risk and another no association between any genotype of VDR polymorphism and fractures. ${ }^{27,28}$ Most of the studies, however, concerned postmenopausal women and older men and thus data regarding the association of the BsmI polymorphism with osteoporosis and fracture risk among the young are scarce.

The COL1A1 and COL1A2 genes encode the two alpha chains (alpha 1 and alpha 2, respectively) of collagen type 1 that trimerize to form the procollagen 1 molecule, ${ }^{29}$ the main component of bone matrix. Mutations in these genes account for approximately $90 \%$ of osteogenesis imperfecta (OI), which is a form of inherited osteoporosis in children characterized by low bone mass, fragile bone with increased fracture risk, blue sclerae, and in some cases impaired odontogenesis. Mild cases of OI can result in the diagnosis of osteoporosis in adulthood or at an advanced age ${ }^{30}$ and, at present, almost 17 genetic causes of OI have been identified. ${ }^{31}$ Several large-scale studies have demonstrated an association between the polymorphism affecting the Sp1 binding site of the COL1A1 gene and low bone mass and increased fracture risk in the general population. ${ }^{32-34}$

The LRP5 gene encodes for the LRP5 co-receptor of the Wnt signaling pathway, which is of critical importance in bone metabolism regulating osteoblastogenesis and bone formation. ${ }^{35} \mathrm{Wnt}$ ligands bind to the Frizzled-LRP 5/6 receptor complex in the cell membrane and activate intracellular Wnt signaling. Activation is mediated either through translocation of the cytoplasmic protein beta-catenin to the nucleus, where it acts as a transcription factor activating the transcription of the target genes (canonical pathway), or via calcium and cAMP signals (non-canonical pathway). Loss-of-function mutations in the LRP5 gene cause the osteoporosis-pseudoglioma syndrome, ${ }^{36}$ an autosomal recessive disorder characterized by severe juvenile-onset osteoporosis and congenital or juvenileonset blindness. ${ }^{37}$ Activating mutations, on the other hand, are responsible for the autosomal dominant high bone mass trait. ${ }^{38}$ In a recent multicenter study of 37,534 participants, it was demonstrated that the V667M (in exon 9) and A1330V (in exon 18) poly- morphisms of the LRP 5 gene are associated with low BMD values and increased risk of fractures. ${ }^{39}$

Our patient suffered from unspecific musculoskeletal symptoms, such as arthralgia and diffuse myalgia, which were initially attributed to seronegative spondyloarthritis, thus delaying the final diagnosis. The lack of evidence of a systemic chronic disease and secondary osteoporosis and the severity of his bone disease with multiple spontaneous vertebral fractures led us to look for a genetic background whereby we were able to further exclude inherited forms of juvenile osteoporosis, such as OI. The co-existence of mutations in more than one of the genes related to osteoporosis in young adults has not been evaluated so far and larger studies are needed to elucidate a possible interaction and synergistic effect between the implicated genes. Administration of teriparatide, as the only bone anabolic agent currently available, followed by an antiresorptive agent and calcium plus vitamin D supplementation proved very effective in our patient, who continues to remain free of symptoms and with no new fractures over a long period of time.

\section{REFERENCES}

1. 1993 Consensus development conference: diagnosis, prophylaxis, and treatment of osteoporosis. Am J Med 94: 646-650.

2. Seeman E, 2002 Pathogenesis of bone fragility in women and men. Lancet 359: 1841-1850.

3. Seeman E, 2004 Estrogen, androgen, and the pathogenesis of bone fragility in women and men. Curr Osteoporos Rep 2: 90-96.

4. Seeman E, 2004 The growth and age-related origins of bone fragility in men. Calcif Tissue Int 75: 100-109.

5. Baim S, Binkley N, Bilezikian JP, et al, 2008 Official Positions of the International Society for Clinical Densitometry and executive summary of the 2007 ISCD Position Development Conference. J Clin Densitom 11: 75-91.

6. Bonjour JP, Chevalley T, Rizzoli R, Ferrari S, 2007 Gene-environment interactions in the skeletal response to nutrition and exercise during growth. Med Sport Sci 51: 64-80.

7. Chevalley T, Rizzoli R, Hans D, Ferrari S, Bonjour JP, 2005 Interaction between calcium intake and menarcheal age on bone mass gain: an eight-year follow-up study from prepuberty to postmenarche. J Clin Endocrinol Metab 90: 44-51.

8. Ferrari S, Bianchi ML, Eisman JA, et al, 2012 Osteoporosis in young adults: pathophysiology, diagnosis, and management. Osteoporos Int 23: 2735-2748. 
9. Estrada K, Styrkarsdottir U, Evangelou E, et al, 2012 Genome-wide meta-analysis identifies 56 bone mineral density loci and reveals 14 loci associated with risk of fracture. Nat Genet 44: 491-501.

10. Richards JB, Kavvoura FK, Rivadeneira F, et al, 2009 Collaborative meta-analysis: associations of 150 candidate genes with osteoporosis and osteoporotic fracture. Ann Intern Med 151: 528-537.

11. Richards JB, Zheng HF, Spector TD, 2012 Genetics of osteoporosis from genome-wide association studies: advances and challenges. Nat Rev Genet 13: 576-588.

12. Morrison NA, Qi JC, Tokita A, et al, 1994 Prediction of bone density from vitamin $\mathrm{D}$ receptor alleles. Nature 367: 284-287.

13. Christakos S, Dhawan P, Liu Y, Peng X, Porta A, 2003 New insights into the mechanisms of vitamin $\mathrm{D}$ action. J Cell Biochem 88: 695-705.

14. Wong HL, Seow A, Arakawa K, Lee HP, Yu MC, Ingles SA, 2003 Vitamin D receptor start codon polymorphism and colorectal cancer risk: effect modification by dietary calcium and fat in Singapore Chinese. Carcinogenesis 24: 1091-1095.

15. Thomas T, Briot K, 2016 Vitamin D, bone metabolism and fracture risk. Geriatr Psychol Neuropsychiatr Vieil 14: 122-126.

16. Liu YZ, Liu YJ, Recker RR, Deng HW, 2003 Molecular studies of identification of genes for osteoporosis: the 2002 update. J Endocrinol 177: 147-196.

17. Arai H, Miyamoto KI, Yoshida M, et al, 2001 The polymorphism in the caudal-related homeodomain protein Cdx-2 binding element in the human vitamin D receptor gene. J Bone Miner Res 16: 1256-1264.

18. Fang Y, van Meurs JB, Bergink AP, et al, 2003 Cdx-2 polymorphism in the promoter region of the human vitamin D receptor gene determines susceptibility to fracture in the elderly. J Bone Miner Res 18: 1632-1641.

19. Riggs BL, Nguyen TV, Melton LJ 3rd, et al, 1995 The contribution of vitamin $\mathrm{D}$ receptor gene alleles to the determination of bone mineral density in normal and osteoporotic women. J Bone Miner Res 10: 991-996.

20. Masi L, Cimaz R, Simonini G, et al, 2002 Association of low bone mass with vitamin d receptor gene and calcitonin receptor gene polymorphisms in juvenile idiopathic arthritis. J Rheumatol 29: 2225-2231.

21. Sainz J, Van Tornout JM, Loro ML, Sayre J, Roe TF, Gilsanz V, 1997 Vitamin D-receptor gene polymorphisms and bone density in prepubertal American girls of Mexican descent. N Engl J Med 337: 77-82.

22. Mencej-Bedrac S, Prezelj J, Kocjan T, et al, 2009 The combinations of polymorphisms in vitamin $\mathrm{D}$ receptor, osteoprotegerin and tumour necrosis factor superfamily member 11 genes are associated with bone mineral density. J Mol Endocrinol 42: 239-247.

23. Gong G, Stern HS, Cheng SC, et al, 1999 The association of bone mineral density with vitamin D receptor gene polymorphisms. Osteoporos Int 9: 55-64.

24. Zintzaras E, Rodopoulou P, Koukoulis GN, 2006 BsmI, TaqI, ApaI and FokI polymorphisms in the vitamin D receptor (VDR) gene and the risk of osteoporosis: a meta-analysis. Dis Markers 22: 317-326.

25. Qin G, Dong Z, Zeng P, Liu M, Liao X, 2013 Association of vitamin D receptor BsmI gene polymorphism with risk of osteoporosis: a meta-analysis of 41 studies. Mol Biol Rep 40: 497-506.

26. Uitterlinden AG, Ralston SH, Brandi ML, et al, 2006 The association between common vitamin $\mathrm{D}$ receptor gene variations and osteoporosis: a participant-level meta-analysis. Ann Intern Med 145: 255-264.

27. Ji GR, Yao M, Sun CY, Li ZH, Han Z, 2010 BsmI, TaqI, ApaI and FokI polymorphisms in the vitamin D receptor (VDR) gene and risk of fracture in Caucasians: a meta-analysis. Bone 47: 681-686.

28. Fang Y, Rivadeneira F, van Meurs JB, Pols HA, Ioannidis JP, Uitterlinden AG, 2006 Vitamin D receptor gene BsmI and TaqI polymorphisms and fracture risk: a meta-analysis. Bone 39: 938-945.

29. Valadares ER, Carneiro TB, Santos PM, Oliveira AC, Zabel B, 2014 What is new in genetics and osteogenesis imperfecta classification? J Pediatr (Rio J) 90: 536-541.

30. O'Sullivan ES, van der Kamp S, Kilbane M, McKenna M, 2014 Osteogenesis imperfecta in adults: phenotypic characteristics and response to treatment in an Irish cohort. Ir J Med Sci 183: 225-230.

31. Van Dijk FS, Sillence DO 2014 Osteogenesis imperfecta: clinical diagnosis, nomenclature and severity assessment. Am J Med Genet A 164A: 1470-1481.

32. Uitterlinden AG, Pols HA, Burger H, et al, 1996 A large-scale population-based study of the association of vitamin D receptor gene polymorphisms with bone mineral density. J Bone Miner Res 11: 1241-1248.

33. Ralston SH, Uitterlinden AG, Brandi ML, et al, 2006 Large-scale evidence for the effect of the COLIA1 Sp1 polymorphism on osteoporosis outcomes: the GENOMOS study. PLoS Med 3: e90.

34. Jin H, van't Hof RJ, Albagha OM, Ralston SH, 2009 Promoter and intron 1 polymorphisms of COL1A1 interact to regulate transcription and susceptibility to osteoporosis. Hum Mol Genet 18: 2729-2738.

35. Yavropoulou MP, Yovos JG, 2007 The role of the Wnt signaling pathway in osteoblast commitment and differentiation. Hormones (Athens) 6: 279-294.

36. Gong Y, Slee RB, Fukai N, et al, 2001 LDL receptorrelated protein 5 (LRP5) affects bone accrual and eye development. Cell 107: 513-523.

37. Gong Y, Vikkula M, Boon L, et al, (1996) Osteoporosispseudoglioma syndrome, a disorder affecting skeletal strength and vision, is assigned to chromosome region 11q12-13. Am J Hum Genet 59: 146-151.

38. Little RD, Carulli JP, Del Mastro RG, et al, 2002 A mutation in the LDL receptor-related protein 5 gene results in the autosomal dominant high-bone-mass trait. Am J Hum Genet 70: 11-19.

39. van Meurs JB, Trikalinos TA, Ralston SH, et al, 2008 Large-scale analysis of association between LRP5 and LRP6 variants and osteoporosis. JAMA 299: 1277-1290. 